VOLUME VIII NUMBER 3

SEPTEMBER 1975

\title{
CENTRAL
}

EUROPEAN

HISTORY

\author{
Sponsored by the \\ Conference Group for Central European History \\ of the American Historical Association \\ PUBLISHED QUARTERLY BY \\ EMORY UNIVERSITY
}




\section{PRIZE ANNOUNCEMENT}

The Conference Group for Central European History awards every two years a prize of \$2 so to the North American scholar who, in the opinion of a prize awards committee, has written the best article dealing with the topic of Central European history. The article must have been published in any scholarly journal in the United States, Canada, or abroad during the two-year period preceding the awarding of the prize.

The prize will be awarded at the business meeting of the Conference Group in December 1976. The Awards Committee consists of Georg G. Iggers, chairman (Department of History, State University of New York at Buffalo, Buffalo, New York 14214), Arnold H. Price (6693 Barnaby Street, N.W., Washington, D.C. 20015), and Peter F. Sugar (Department of History, University of Washington, Seattle, Washington 98195). The committee will consider articles published since October 15,1974 . Articles may be submitted by their authors, the editors of journals in which they have been published, or anyone else who wishes to recommend them for the prize. One copy of each article should be sent directly before October 15, 1976, to each member of the committee.

The subscription rates for Central European History are as follows:

United States and possessions:

$\begin{array}{lcc} & \text { INDrVIDUALS } & \text { INSTITUTIONS } \\ 1 \text { year } & \$ 12 & \$ 18 \\ 2 \text { years } & \$ 22 & \$ 35 \\ 3 \text { years } & \$ 30 & \$ 50 \\ \text { Student and emeritus rate } & \$ 6 \text { per year } \\ \text { Subscriptions by calendar year only. }\end{array}$

All other countries: Add \$1 per year for mailing.

Back issues: All back volumes, starting with Volume I (1968), are available at $\$ 12$ for individuals, $\$ 18$ for institutions; outside U.S. and possessions, add $\$ 1$ per volume for mailing. For student and emeritus prices, please inquire.

Address: Central European History, Emory University, Atlanta, Georgia 30322. 


\section{CENTRAL EUROPEAN HISTORY}

\section{ARTICLES}

Militarism and the Development of Fascist Ideology: The 199 Political Ideas of Colonel Max Bauer, 1916-18 BY MARTIN KITCHEN

Germany and the Eupen-Malmédy Affair 1924-26: "Here

Lies the Spirit of Locarno"

BY ROBERT P. GRATHWOL

A Jewish Collaborator in Nazi Germany: The Strange

Career of Georg Kareski, 1933-37

BY HERBERT S. LEVINE

\section{REVIEWS}

Otto Büsch, ed., Untersuchungen zur Geschichte der frühen

Industrialisierung vornehmlich im Wirtschaftsraum Berlin/Brandenburg; Otto Büsch, Industrialisierung und Gewerbe im Raum Berlin/Brandenburg, 1800-1850 BY RICHARD TILLY

Richard Georg Plaschka et al., Innere Front: Militärassistenz, Widerstand und Umsturz in der Donaumonarchie 1918 BY ROBERT A. KANN 


\section{CENTRAL EUROPEAN HISTORY}

Sponsored by the Conference Group for Central European History of the American Historical Association

Published quarterly by Emory University, Atlanta, Georgia 30322

\section{BOARD OF EDITORS}

CLAUS-PETER CLASEN

University of Califormia, Los Angeles

ANDREAS DORPALEN

Ohio State University

GERALD D. FELDMAN

University of California, Berkeley

MARTIN JAY

University of California, Berkeley
ALLAN MITCHELL

University of California, San Diego

LENORE O'BOYLE

Cleveland State University

DIETRICH ORLOW

Boston University

PAUL W. SCHROEDER

University of Illinois

MACK WALKER

Cornell University

Editor

DOUGLAS A. UNFUG

Assistant Editor

THEODOR V. BRODEK
Business Manager

OLIVIA J. HARRIS

All correspondence should be sent to Central European History, Emory University, Atlanta, Georgia 30322. $\$$ Subscription rates for United States and possessions: Individuals 1 year $\$ 12$ (U.S.), 2 years $\$ 22,3$ years $\$ 30$. Student and emeritus rate $\$ 6$ a year. Single copies $\$ 3.25$. Institutions 1 year $\$ 18,2$ years $\$ 35,3$ years $\$ 50$. Single copies $\$ 4.75$. \$ All other countries: Add $\$ 1$ per year (25c per single copy) for mailing. $\$$ Subscriptions by calendar year only. $\$$ Individual subscriptions include membership in the Conference Group for Central European History. All subscriptions postpaid. Checks should be made out to Central European History. $\$$ Second-class postage paid at Atlanta, Georgia, and at additional mailing offices. Published quarterly in March, June, September, and December. $\$$ Central European History is indexed or abstracted in Historical Abstracts, Humanities Index, Book Review Index, Internationale Bibliographie der Zeitschrifienliteratur (IBZ), Current Contents / Social and Behavioral Science, Social Sciences Citation Index, Universal Reference System, and BA-SIS-H Service of the Nexus Corporation. $\$$ Copyright $(1976$ by Emory University. All rights reserved. $₫$ Printed by The Stinehour Press, Lunenburg, Vermont. ISSN $0008-9389$ 